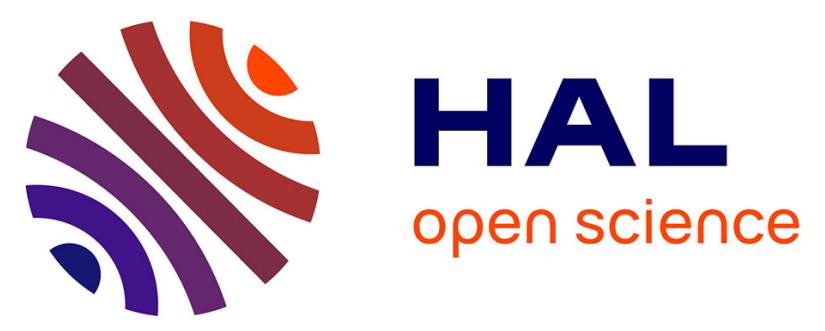

\title{
Mineralization Enhancement of Pharmaceutical Contaminants by Radical-Based Oxidation Promoted by Oxide-Bound Metal Ions
}

Mahamadou Kamagate, Mathieu Pasturel, Marcello Brigante, Khalil Hanna

\section{- To cite this version:}

Mahamadou Kamagate, Mathieu Pasturel, Marcello Brigante, Khalil Hanna. Mineralization Enhancement of Pharmaceutical Contaminants by Radical-Based Oxidation Promoted by Oxide-Bound Metal Ions. Environmental Science and Technology, 2020, 54 (1), pp.476-485. 10.1021/acs.est.9b04542 . hal-02442225

HAL Id: hal-02442225

https://hal-univ-rennes1.archives-ouvertes.fr/hal-02442225

Submitted on 13 Feb 2020

HAL is a multi-disciplinary open access archive for the deposit and dissemination of scientific research documents, whether they are published or not. The documents may come from teaching and research institutions in France or abroad, or from public or private research centers.
L'archive ouverte pluridisciplinaire HAL, est destinée au dépôt et à la diffusion de documents scientifiques de niveau recherche, publiés ou non, émanant des établissements d'enseignement et de recherche français ou étrangers, des laboratoires publics ou privés. 
1 Mineralization enhancement of pharmaceutical contaminants by radicalbased oxidation promoted by oxide-bound metal ions

${ }^{1}$ Univ Rennes, Ecole Nationale Supérieure de Chimie de Rennes, UMR CNRS 6226, 11 Allée de Beaulieu, F-35708 Rennes Cedex 7, France.

$8 \quad$ 2Université de Man, BP 20 Man, Côte d'Ivoire.

9

${ }^{5}$ Institut Universitaire de France (IUF), MESRI, 1 rue Descartes, 75231 Paris Cedex.

*Corresponding author: khalil.hanna@ensc-rennes.fr / +332 23238027

${ }^{4}$ Université Clermont Auvergne, CNRS, SIGMA Clermont, Institut de Chimie de ClermontFerrand, F-63000 Clermont-Ferrand, France.

${ }^{3}$ Univ Rennes, Université de Rennes 1, UMR CNRS 6226, Avenue General Leclerc, F-35708 Rennes Cedex 7, France.

* Corresponding author: khalil.hanna@ensc-rennes.fr/ 33223238027

(7)

18

9

20

1

December, 2019 


\section{$27 \quad$ Abstract}

While the use of transition metal oxides in catalyzing advanced oxidation reactions has been widely investigated, very few reports have focused on how the preliminary contact of oxides with target compounds may affect the succession of reaction. In this study, we examined the adsorption and electron transfer reactions of two fluoroquinolones, flumequine (FLU) and norfloxacin (NOR), with goethite $(\alpha-\mathrm{FeOOH})$ or manganese $(\mathrm{Mn})$ oxide, and their impact on the subsequent mineralization of target compounds using $\mathrm{H}_{2} \mathrm{O}_{2}$ or $\mathrm{S}_{2} \mathrm{O}_{8}{ }^{2-}$ under UVA irradiation. Intriguingly, higher total organic carbon (TOC) removal was achieved when antibiotics and metal-oxides were allowed for pre-equilibration before starting the oxidation reaction. The rate and extent of TOC removal is strongly dependent on the molecule structure and the redox-active mineral used, and much less on the pre-equilibration time. This high efficiency can be ascribed to the presence of reduced metal ions, chemically or photochemically generated during the first stage, onto oxide minerals. Oxide-bound $\mathrm{Mn}^{\mathrm{II}}$ plays a crucial role in catalyzing oxidant decomposition and then producing greater amounts of radical species through a photo-assisted redox cycle, regardless of the underlying surface, $\mathrm{Mn}^{\mathrm{IV}} \mathrm{O}_{2}$ or $\mathrm{Mn}^{\mathrm{III}} \mathrm{OOH}$. This finding will be of fundamental and practical significance to Mnbased oxidation reactions and wastewater treatment processes. 


\section{Introduction}

Fe- and Mn- oxyhydroxides, commonly found in the Earth's near-surface environment, are generally the dominant sorbents and redox-active compounds in the environment ${ }^{1-2}$. Interactions of these oxides with organic compounds may involve the adsorption associated or not with a heterogeneous redox reaction. The latter, which is typically attributed to sequential one electron-transfer reactions, results in reductive dissolution of the oxide into reduced ions (e.g. $\mathrm{Fe}^{\mathrm{II}}$ or $\mathrm{Mn}^{\mathrm{II}}$ ) and oxidative transformation of the molecule into oxidized products ${ }^{3-5}$. These interactions are mainly affected by solution $\mathrm{pH}$, oxide surface properties, and structural characteristics of target compound ${ }^{6-13}$.

The heterogeneous electron transfer reactions are generally studied in the context of characterization of affected environments, as the fate of organic contaminants is often tied to their affinities to surfaces of soil and sediment mineral particles. Some reports contend that theses reactions can also be applied in water and wastewater treatment technologies ${ }^{11-13}$, even though there is no total effective destruction of target contaminants. Indeed, one electrontransfer reactions with $\mathrm{Mn}$ - or Fe-oxides produce a suite of products, including ring-cleavage products or dehalogenated products ${ }^{5-10}$. Although they could modify the contaminant structure, they are not able to achieve total mineralization, i.e., their complete conversion to $\mathrm{CO}_{2}$ and/or inorganic ions. The latter may be achieved by advanced oxidation processes which are a set of techniques based on the catalytic decomposition of oxidants, hydrogen peroxide $\left(\mathrm{H}_{2} \mathrm{O}_{2}\right)$ or persulfate $\left(\mathrm{S}_{2} \mathrm{O}_{8}{ }^{2-}\right)^{14-16}$, and then the formation of strongly reactive transient species such as the hydroxyl radical, ${ }^{\bullet} \mathrm{OH}(2.8 \mathrm{~V})$, or the sulfate radical, $\mathrm{SO}_{4}^{\bullet-}(2.5-$ $3.1 \mathrm{~V})^{17-18}$

In this work, we examined, for the first time, how the electron transfer reactions between organic contaminants and redox-active minerals can determine the subsequent total removal or mineralization of target compounds. For this purpose, we first studied the reaction (i.e., 
adsorption and/or heterogeneous redox reactions) of two kinds of fluoroquinolone antibiotics with goethite $(\alpha-\mathrm{FeOOH})$ and manganese oxide $\left(\mathrm{MnO}_{2}\right)$, which are the most common redoxactive minerals in terrestrial and marine environments. The formation of byproducts and reduced metal ions during the first stage of reaction was also monitored. Flumequine (FLU) and norfloxacin (NOR) were selected because of their growing use in human and veterinary medicine and continuous release into the environment, resulting in their large presence in surface waters, groundwaters and sediments at concentrations levels ranging from ng to $\mu \mathrm{g}$ per L ${ }^{19-20}$. Fluoroquinolones such as NOR are electron donor-acceptor compounds with the piperazinyl group serving as the electron donor and 4-oxoquinoline-3-carboxylic acid as the electron acceptor in the neutral and zwitterion forms.

The catalytic decomposition of $\mathrm{H}_{2} \mathrm{O}_{2}$ or $\mathrm{Na}_{2} \mathrm{~S}_{2} \mathrm{O}_{8}$ and degradation/mineralization of target compounds were then investigated in presence of $\mathrm{MnO}_{2}$ or $\alpha-\mathrm{FeOOH}$, under dark and UVA irradiation. We also evaluated the impact of pre-equilibration time (i.e., first contact between molecules and oxides) on the mineralization of compounds through hydroxyl/sulfate radical based oxidation processes. Radical scavengers and Laser Flash Photolysis (LFP) experiments were performed to assess the involved radical species and their reactivity with generated byproducts. To assess the contribution of $\mathrm{Mn}^{\mathrm{IV}}$ and $\mathrm{Mn}^{\mathrm{III}}$ in the overall reaction, Mn-oxides with lower valence states as in manganite $\left(\gamma-\mathrm{Mn}^{\mathrm{III}} \mathrm{OOH}\right)$ were investigated, and the role played by mineral-bound $\mathrm{Mn}^{\mathrm{II}}$ on the heterogeneous oxidation process was discussed. 


\section{Materials and methods}

91

92

\subsection{Chemicals}

All chemicals were of pro-analytical quality or better and purchased from SigmaAldrich, France. FLU (purity $>99 \%$ ) and NOR (purity $>98 \%$ ) stock solutions were prepared separately by dissolving $20 \mathrm{mg}$ of both chemicals in $0.5 \mathrm{~mL}$ of $1 \mathrm{M} \mathrm{NaOH}$, then diluted to $1 \mathrm{~L}$ with ultrapure water. Hydrogen peroxide $\left(\mathrm{H}_{2} \mathrm{O}_{2}, 35 \%\right.$ w/w) and sodium persulfate (PS) $\left(\mathrm{Na}_{2} \mathrm{~S}_{2} \mathrm{O}_{8}>99.5 \%\right.$ purity) were also provided by Sigma-Aldrich. Sulfuric acid, Sodium hydroxide, Manganese (II) nitrate tetrahydrate $\left(\mathrm{Mn}\left(\mathrm{NO}_{3}\right)_{2} \cdot{ }_{4} \mathrm{H}_{2} \mathrm{O}\right)$, 2-propanol $\left(2-\mathrm{Pr}, \mathrm{C}_{3} \mathrm{H}_{8} \mathrm{O}\right)$, $t$-butanol ( $t$-but, $\mathrm{C}_{4} \mathrm{H}_{10} \mathrm{O}$ ) were obtained from Sigma-Aldrich. Solutions were prepared with high-purity water obtained from a Millipore Milli-Q system.

Goethite $(\alpha-\mathrm{FeOOH})$, manganite $(\gamma-\mathrm{MnOOH})$ and manganese oxide $\left(\mathrm{MnO}_{2}\right)$ particles were synthesized as described in previous studies ${ }^{21-23}$. The nature of goethite and manganite was confirmed by X-ray diffraction (XRD) (Fig. S1). The diffractogram of manganese oxide corresponds to that of pyrolusite (Fig S1). The B.E.T. specific surface area of $\alpha-\mathrm{FeOOH}, \gamma-$ $\mathrm{MnOOH}$ and $\mathrm{MnO}_{2}$ were $85 \pm 1,64 \pm 1$ and $371 \pm 5 \mathrm{~m}^{2} \mathrm{~g}^{-1}$, respectively. The point of zero charge (PZC) determined from potentiometric titration of $\mathrm{MnO}_{2}$ and $\mathrm{MnOOH}$ were 2.4 and 6.3, respectively, whereas that of goethite was 9.1. Mn average oxidation state (AOS) of pyrolusite was measured by a back-titration method using a $\mathrm{KMnO}_{4}$ standard solution. ${ }^{24} \mathrm{AOS}$ of the $\mathrm{MnO}_{2}$ used in this study was determined as 3.95.

\subsection{Adsorption, redox and Laser Flash Photolysis experiments}

Solubility experiments were conducted by suspending separately FLU and NOR powders $(\sim 4-6 \mathrm{mg})$ in $10 \mathrm{~mL}$ water solution containing $\mathrm{NaCl}(10 \mathrm{mM})$ as a function of $\mathrm{pH}$. The suspensions were equilibrated for $24 \mathrm{~h}$, thereafter the supernatants were filtered $(0.2 \mu \mathrm{m})$. Then, FLU and NOR concentrations were measured by high-performance liquid 
chromatography (HPLC, Waters 600 controller with a C18 column $(250 \mathrm{~mm} \times 4.6 \mathrm{~mm}$ i.d., 5 $\mu \mathrm{m})$. Solubility is relatively low at acidic $\mathrm{pH}$ for FLU $(\sim 80 \mu \mathrm{M})$ and between $\mathrm{pH} 7$ and 8 for $\operatorname{NOR}(\sim 1200 \mu \mathrm{M})$ (Fig. S2).

Adsorption and redox kinetics were then evaluated at $\mathrm{pH}=6.5 \pm 0.1, \mathrm{NaCl}$ concentration $=10 \mathrm{mM}$, NOR initial concentration $=24 \mu \mathrm{M}$, FLU initial concentration $=24$ $\mu \mathrm{M}$ with $\alpha-\mathrm{FeOOH}$ and $\mathrm{MnO}_{2}$ concentration $=10 \mathrm{~m}^{2} \mathrm{~L}^{-1}$. All batch experiments were performed under an atmosphere of $\mathrm{N}_{2}(\mathrm{~g})$ to purge dissolved $\mathrm{CO}_{2}$ from the aqueous solutions. Because the adsorption of target compounds is negligible at $\mathrm{pH}$ higher than 10 (according to preliminary adsorption tests), desorption tests were conducted at $\mathrm{pH}=11$ as a means to check the mass balance. Amount of $\mathrm{Mn}^{\mathrm{II}}$ released in the reaction solution was monitored by Atomic Absorption Spectrometer (Varian AA 140). Possible generation of dissolved ferrous ion was assessed by UV-visible spectrophotometry (Cary 50 probe, Varian) using the 1-10 phenanthroline method.

Aqueous concentrations of NOR and FLU were determined using a Waters 600 controller high performance liquid chromatography (HPLC) system equipped with an autosampler (Waters 717 plus), a C18 column $(250 \mathrm{~mm} \times 4.6 \mathrm{~mm}$ i.d., $5 \mu \mathrm{m})$ and a UV detector (246 $\mathrm{nm}$ for FLU or $277 \mathrm{~nm}$ for NOR, Waters 2489). The mobile phase was a mixture of water/acetonitrile $(60: 40 \mathrm{v} / \mathrm{v})$ containing $0.1 \%$ of formic acid. The flow rate of the mobile phase was set at $1 \mathrm{~mL} \mathrm{m^{-1 }}$ in an isocratic mode. Under these conditions, the retention times of FLU and NOR were 6.5 and $7.5 \mathrm{~min}$, respectively.

Oxidation by-products were analyzed with a water ultrapure HPLC-MS/MS (Acquity UPLC) system, equipped with a BEH C18 column (100 $\mathrm{mm} \times 2.1 \mathrm{~mm}, 1.7 \mu \mathrm{m})$. The mobile phase consisted of acetonitrile containing $0.1 \%$ of formic acid (eluant A) and mixture acetonitrile/water (i.e., $10 \%$ / $90 \%$ ) containing $0.1 \%$ of formic acid (eluant B) with gradient $0 \min / 0 \% \mathrm{~A}-1 \mathrm{~min} / 0 \% \mathrm{~A}-9 \mathrm{~min} / 100 \% \mathrm{~A}-12 \mathrm{~min} / 0 \% \mathrm{~A}$ and a flow rate equal to 400 
$139 \mu \mathrm{L} \mathrm{min}{ }^{-1}$. An electrospray ionization (ESI) was used for the MS measurements in positive 140 ionization mode and full scan acquisition.

The reactivity of NOR or FLU and their byproducts with radical species was monitored

142 using a Laser Flash Photolysis apparatus (LFP), following previously reported procedure. ${ }^{25}$ Briefly, a laser flash photolysis system using $266 \mathrm{~nm}$ excitation wavelength (pulse energy of $45 \mathrm{~mJ}$ ) is used to generate hydroxyl and sulfate radical from $\mathrm{H}_{2} \mathrm{O}_{2}$ and PS solutions in the presence of different concentrations of fluoroquinolone. Aliquots of chemical solutions (FLU, NOR, $\mathrm{S}_{2} \mathrm{O}_{8}{ }^{2-}, \mathrm{H}_{2} \mathrm{O}_{2}$, etc.) were mixed just before each LFP experiment to obtain the desired concentrations. Reactivity of FLU with hydroxyl radical was determined by using chemical competition kinetics with thiocyanate anion $\left(\mathrm{SCN}^{-}\right)$and consequent formation of dithyociante radical anion $\left(\mathrm{SCN}_{2}{ }^{-}\right)$detected at $470 \mathrm{~nm}$. Absorption of $\mathrm{SCN}_{2}{ }^{-}$transient was correlated to the competitive reactivity between $\bullet \mathrm{OH}$ and fluoroquinolones in solution to obtain the second order rate constant. ${ }^{25}$ The second-order rate constant for the reactivity between $\mathrm{SO}_{4}{ }^{\bullet-}$ and $\mathrm{NOR}$ or FLU, was determined from the slope of the linear correlation between the first-order decay constant of the radical, determined from the regression lines of the logarithmic decays of $\mathrm{SO}_{4}{ }^{\bullet-}$ signal monitored at $450 \mathrm{~nm}$, and the initial concentration of fluoroquinolone. Each error was obtained from the scattering of the experimental data from the fitting line. The constant was reported as $\mathrm{L} \mathrm{mgC}^{-1} \mathrm{~s}^{-1}$ after determination of carbon concentration $\left(\mathrm{mgC} \mathrm{L}^{-1}\right)$ using TOC analyser of each sample. Experiments were performed at pH 3 and 9 for FLU (pKa 6.3) and at pH 3.5, 7.5 and 11 for NOR (pKa 6.2 and 8.5) in order to determine the reactivity of neutral and deprotonated forms, which coexist at $\mathrm{pH} 6.5$.

\subsection{UVA irradiation experiments}

A photoreactor (made of borosilicate glass) of $500 \mathrm{~mL}$ capacity was used to perform all experiments at $\mathrm{pH} 6.5 \pm 0.1$. The tubular reactor, $34 \mathrm{~cm}$ high and $3.8 \mathrm{~cm}$ in diameter, was designed. This setup has an enclosed chamber comprising this reactor; an UVA lamp $24 \mathrm{~W}$ 
(Philips PL-L) placed in the center of the glass cell emitting in a wavelength region 320-400 $\mathrm{nm}$ with the emission peak centered at $\lambda_{\max }=360 \mathrm{~nm}$, yielding a irradiation intensity of 16 $\mathrm{mW} \mathrm{cm} \mathrm{cm}^{-2}$ quantified with an UVA Radiometer (VLX- 3W equipped with a sensor CX 365, ALYS Technologies, Switzerland). The solution with catalysts was continuously stirred with a magnetic bar at $180 \mathrm{rpm}$. The $\mathrm{pH}$ of the sample solution was measured with a VWR instruments $6000 \mathrm{pH}$-meter. Monitoring of suspension temperature indicated no significant fluctuation $\left(20 \pm 2{ }^{\circ} \mathrm{C}\right)$ along the experiment.

Two different experiments were conducted at room temperature. In the first series of experiments, FLU or NOR, oxidants $\left(\mathrm{H}_{2} \mathrm{O}_{2}\right.$ or $\left.\mathrm{S}_{2} \mathrm{O}_{8}{ }^{2-}\right)$ and oxides $\left(\alpha-\mathrm{FeOOH}\right.$ or $\left.\mathrm{MnO}_{2}\right)$ were mixed simultaneously few minutes before UVA irradiation. In the second experimental series, suspensions containing antibiotics and goethite or manganese oxide were stirred in the dark for a certain time $(1,24$, or $48 \mathrm{~h})$ before adding oxidant and/or starting UVA irradiation.

In both experiments, $0.059 \mathrm{~g}$ of goethite or $0.0135 \mathrm{~g}$ of $\mathrm{MnO}_{2}$ were added to $500 \mathrm{~mL}$ of contaminant solution and the $\mathrm{pH}$ was kept constant $(6.5 \pm 0.1)$ using $\mathrm{NaOH}$ or $\mathrm{H}_{2} \mathrm{SO}_{4}$. At each time interval, an aliquot of solution was collected to determine the aqueous concentration of FLU or NOR by HPLC/UV. Total Organic Carbon (TOC) was determined using a TOCmeter (Shimadzu TOC-VCSH). All experiments were conducted in triplicates and showed a good reproducibility within $5 \%$ of relative standard deviation.

\section{Results and discussion}

\subsection{Assessment of adsorption and electron transfer reactions on mineral surfaces}

Sorption kinetics of FLU onto $10 \mathrm{~m}^{2} \mathrm{~L}^{-1}$ of oxide $\left(\alpha-\mathrm{FeOOH}\right.$ or $\left.\mathrm{MnO}_{2}\right)$ with $10 \mathrm{mM}$ $\mathrm{NaCl}$ at $\mathrm{pH}=6.5 \pm 0.1$ conducted over a 6-day period showed that a steady-state was achieved within approximately $20 \mathrm{~h}$ of reaction time (Fig. S3). Mass balance showed that FLU was removed only by adsorption (i.e., $\sim 40 \%$ of FLU was sorbed onto $10 \mathrm{~m}^{2} \mathrm{~L}^{-1}$ of $\alpha$ - 
FeOOH or $\mathrm{MnO}_{2}$, respectively), and that transformation by oxidation did not occur under the experimental conditions of this study. As widely reported for organic ligands, adsorption kinetics onto mineral surfaces could be described according to the pseudo-first-order equation. The pseudo-first-order apparent rate constant $k_{a p p}\left(\mathrm{~min}^{-1}\right)$ obtained by linear regression of $-\ln \left([\mathrm{FLU}]_{\mathrm{aq}} /[\mathrm{FLU}]_{\mathrm{o}}\right)$ versus time were found close for $\alpha-\mathrm{FeOOH}\left(0.15 \mathrm{~min}^{-1}\right)$ and $\mathrm{MnO}_{2}\left(0.17 \mathrm{~min}^{-1}\right)$.

Both adsorption and oxidation appear to be involved in the removal of NOR in presence higher redox potential, i.e., $\mathrm{Mn}{ }^{\mathrm{III}} / \mathrm{Mn}^{\mathrm{II}}$ being more electron acceptor than $\mathrm{Fe} \mathrm{III}^{\mathrm{II}} / \mathrm{Fe}^{\mathrm{II}}$ 3-5 :

$$
\begin{array}{ll}
\mathrm{Fe}^{\mathrm{III}} \mathrm{OOH}_{(\mathrm{s})}+3 \mathrm{H}^{+}+\mathrm{e}^{-} \longrightarrow \mathrm{Fe}^{2+}{ }_{(\mathrm{aq})}+2 \mathrm{H}_{2} \mathrm{O} & \mathrm{E}^{\circ}=+0.67 \mathrm{~V} \\
\mathrm{Mn}^{\mathrm{III}} \mathrm{OOH}_{(\mathrm{s})}+3 \mathrm{H}^{+}+\mathrm{e}^{-} \longrightarrow \mathrm{Mn}^{2+}{ }_{(\mathrm{aq})}+2 \mathrm{H}_{2} \mathrm{O} & \mathrm{E}^{\circ}=+1.50 \mathrm{~V} \\
\mathrm{Mn}^{\mathrm{IV}} \mathrm{O}_{2(\mathrm{~s})}+4 \mathrm{H}^{+}+2 \mathrm{e}^{-} \longrightarrow \mathrm{Mn}^{2+}{ }_{(\mathrm{aq})}+2 \mathrm{H}_{2} \mathrm{O} & \mathrm{E}^{\circ}=+1.23 \mathrm{~V}
\end{array}
$$

The disappearance kinetics of compounds undergoing adsorption/transformation process on metal oxides cannot be described by simple equations that include classical exponential functions (e.g., pseudo-first order model). Instead, we calculated an initial rate constant $\left(k_{\text {in }}\right.$ in $\min ^{-1}$ ) over the first stage of reaction (i.e., $60 \mathrm{~min}$ ) by plotting a linear regression of $\ln \left([\mathrm{NOR}]_{\mathrm{aq}} /[\mathrm{NOR}]_{0}\right)$ versus time, and we found $0.19 \mathrm{~min}^{-1}$ for $\alpha-\mathrm{FeOOH}$ and $0.32 \mathrm{~min}^{-1}$ for $\mathrm{MnO}_{2}$. This behavior has been attributed to the complexity of involved reactions including 207 formation of precursor complex, dissolution of reduced metal, accumulation of reaction products and/or a gradual change of the reactivity of surface sites. In $\mathrm{MnO}_{2} / \mathrm{NOR}$ system, an increase in dissolved $\mathrm{Mn}^{\mathrm{II}}$ concentration was observed over time, confirming that NOR has been oxidized by $\mathrm{MnO}_{2}$ under dark conditions (Fig. 1). However, the measured amount does not correspond to the stoichiometric amount with 
respect to the NOR degradation, most likely due to strong adsorption of $\mathrm{Mn}^{\mathrm{II}}$ ions to $\mathrm{MnO}_{2}$ surfaces at $\mathrm{pH} 6.5$ (see below for more details). In case of goethite, dissolved $\mathrm{Fe}^{\mathrm{II}}$ ion was below detection limit (i.e. $0.2 \mu \mathrm{M}$ ), probably because of the low amount of generated $\mathrm{Fe}^{\mathrm{II}}$ (low oxidation extent, Fig. S3), and strong binding of $\mathrm{Fe}^{\mathrm{II}}$ to $\mathrm{FeOOH}$ surfaces at $\mathrm{pH} 6.5$ and subsequent oxidation of adsorbed $\mathrm{Fe}^{\mathrm{II}} 10$.

Unlike FLU, NOR binding is followed by an electron transfer process resulting in the concomitant oxidation of NOR and reduction of surface-bound metal. In case of $\mathrm{MnO}_{2}$, one electron is transferred from ligand to the surface-bound $\mathrm{Mn}^{\mathrm{IV}}$ to yield radical intermediate and $\mathrm{Mn}^{\mathrm{III}}$ that can be further reduced to give $\mathrm{Mn}^{\mathrm{II}}$. Subsequently, the formed radical intermediate $\left(\mathrm{NOR}^{\circ}\right)$ may undergo several different reaction pathways to yield a range of byproducts as follows:

$\equiv \mathrm{Mn}^{\mathrm{IV}}+\mathrm{NOR} \rightarrow \equiv \mathrm{Mn}^{\mathrm{IV}}-\mathrm{NOR}_{\mathrm{ad}} \rightarrow \equiv \mathrm{Mn}^{\mathrm{III}} / \mathrm{Mn}^{\mathrm{II}}-\mathrm{NOR}^{+\cdot} \rightarrow \mathrm{Mn}^{\mathrm{II}}+\mathrm{NOR}_{\mathrm{ox}}$

Although both FLU and NOR may form similar surface complexes with metal surfaces (i.e. metal-bonded complexes with surface sites and/or directly hydrogen-bonded complexes with surface hydroxo groups) ${ }^{10,21,27}$, oxidative transformation was only observed for NOR. Since FLU does not contain a piperazine ring, we may suppose that the piperazine moiety, the electron donor group, should play a critical role in the molecular transformation with FeOOH or $\mathrm{MnO}_{2}$. This phenomenon has been proposed in previous work 6 to explain why four fluoroquinolones all containing a piperazine moiety exhibited a very similar oxidation rate. The nature of primary oxidation byproducts identified in the present work as a result of dealkylation and hydroxylation at the piperazine moiety ${ }^{6}$, further supports this hypothesis. Indeed, two main byproducts were detected by LC/MS/MS analysis conducted on NOR solution reacted with $\mathrm{MnO}_{2}$ for $22 \mathrm{~h}$ (Fig. S4). The first $(\mathrm{m} / \mathrm{z}=251, \mathrm{M}-69)$ is supposed to form through $\mathrm{N}$-dealkylation of the piperazine ring with a final aniline functional group, while 
the second $(\mathrm{m} / \mathrm{z}=350, M+30)$ could correspond to C-hydroxylation of the piperazine moiety, with two additional $>\mathrm{C}=\mathrm{O}$ groups in the $\mathrm{M}+30$ product (Fig. S4).

\subsection{Assessment of radical-based oxidation in presence of $\mathrm{H}_{2} \mathrm{O}_{2}$ or PS under UVA irradiation}

The addition of oxidant to the initial suspension allowed much better removal extent in $\mathrm{MnO}_{2}$ than in goethite after 300 min of reaction time (Figs. S5 \& S6). In all experiments, the direct photolysis of two pollutants is less than $10 \%$ and the degradation resulting from photochemical activation of oxidants less than $20 \%$ (Figs. S5 \& S6). The removal resulting upon irradiation of solids (i.e. oxide/UV systems) is depended on the oxide surface and molecule. For NOR, $90 \%$ with $\mathrm{MnO}_{2}$ and $20 \%$ with goethite were observed (Figs. S6), which are similar to those observed under dark conditions (i.e. through sorption and heterogeneous redox reactions, Fig. S3), ruling out additional contribution of light. For FLU, almost $30 \%$ of FLU removal was observed for both solids under UVA irradiation (Fig. S5), which corresponds to the sorption reaction (Fig. S3), confirming that contribution of ligand to metal charge transfer is small to negligible under our experimental conditions.

$\mathrm{MnO}_{2}$ exhibited more efficiency for thermal activation of oxidants $\left(\mathrm{H}_{2} \mathrm{O}_{2}\right.$ or PS) than goethite, while the combination with UVA showed the best performance (i.e. > $95 \%$ of FLU or NOR were removed). To account for the adsorption on solids (goethite or $\mathrm{MnO}_{2}$ ), desorption tests (adding $\mathrm{NaOH}$ to reach $\mathrm{pH}$ 11) were carried out and total amounts of FLU or NOR were plotted against time (Figs. S5 \& S6). We also monitored the time-trend of TOC in oxidation systems. About $30 \%$ of mineralization of NOR was obtained for $\mathrm{H}_{2} \mathrm{O}_{2} / \mathrm{MnO}_{2}$ and $\mathrm{PS} / \mathrm{MnO}_{2}$ systems, while $16 \%$ and $20 \%$ were achieved for $\mathrm{H}_{2} \mathrm{O}_{2} /$ goethite and PS/goethite, respectively (Fig. 2). UVA irradiation allowed more TOC removal, but did not achieve complete mineralization (Fig. 2 for NOR and Fig.S7 for FLU). 
Previous works reported that superoxide radical $\left(\mathrm{O}_{2}^{\bullet-}\right)$ is the dominant reactive species generated in the thermal catalyzed decomposition of $\mathrm{H}_{2} \mathrm{O}_{2}$ by $\mathrm{MnO}_{2}$ at neutral $\mathrm{pH}$, and at high concentration of $\mathrm{H}_{2} \mathrm{O}_{2}$ (i.e. $\left.>7.5 \mathrm{mM}\right)^{14}$, 28 . In the case of $\mathrm{MnO}_{2}$-catalyzed activation of PS, several works showed that the Mn(IV)-oxides catalytically decompose PS into sulfate radicals $\left(\mathrm{SO}_{4}^{-}\right)$and hydroxyl radicals $\left({ }^{\circ} \mathrm{OH}\right){ }^{9,}{ }^{29-30}$. However, a recent work has identified singlet oxygen $\left({ }^{1} \mathrm{O}_{2}\right)$ as the primary species during PS activation by pyrolusite $\left(\beta-\mathrm{MnO}_{2}\right)$, which can be generated by direct oxidation or recombination of superoxide ions and radicals from a metastable manganese intermediate at neutral $\mathrm{pH}^{31}$. In the present work and under UVA irradiation, insights into degradation pathways with minerals + oxidants + UVA could be obtained by studying the effects of 2-propanol (2-Pr) and tert-butyl alcohol ( $t$-but), because of their different selectivity (i.e., second-order rate constants) with hydroxyl and sulfate radicals. 2-Pr reacts with both $\bullet^{\bullet} \mathrm{OH}$ and $\mathrm{SO}_{4}^{\bullet}$, with the second-order reaction constant $k_{H O} \cdot 2-P r=$

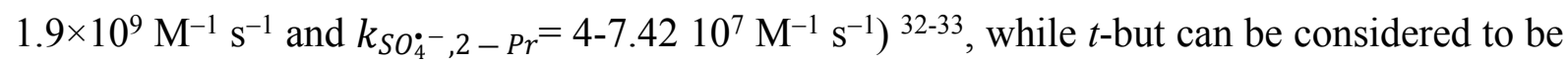
more selective toward $\left.{ }^{\circ} \mathrm{OH} k_{H O \bullet, t-\text { but }}=6.0 \times 10^{8} \mathrm{M}^{-1} 1 \mathrm{~s}^{-1}\right)$ than $\mathrm{SO}_{4}{ }^{\cdot-}\left(k_{S_{4_{4}}^{-}, t-\text { but }}=4-8.4 \times 10^{5}\right.$ $\left.\mathrm{M}^{-1} \mathrm{~s}^{-1}\right)^{32-34}$. For an accurate assessment of reactivity with radical species, we have also determined the bimolecular reaction rate constants with ${ }^{\bullet} \mathrm{OH}$ and $\mathrm{SO}_{4}{ }^{\bullet-}$ at different $\mathrm{pH}$ values (Table 1 and Fig. S8). At the working $\mathrm{pH}$ (6.5), both protonated and ionized forms of FLU may co-exist (See Fig. S2 for distribution of species vs $\mathrm{pH}$ ). Radical scavenging experiments were only performed with FLU, because of the fast heterogeneous oxidation reaction of NOR with metal oxides.

According to scavenging experiments, 2-propanol has strongly inhibited the FLU degradation at $0.5 \mathrm{mM}$ of $\mathrm{H}_{2} \mathrm{O}_{2}$ (Fig. S9), suggesting that the ${ }^{\bullet} \mathrm{OH}$ was by far the dominant reactive species accounting for almost $95 \%$ of degradation. When PS was used instead of $\mathrm{H}_{2} \mathrm{O}_{2}$, inhibition observed with $t$-but used as selective scavenger of $\bullet \mathrm{OH}$ compared to 2-Pr suggested that the degradation would prevalently take place upon reaction with $\mathrm{SO}_{4}{ }^{--}$(Fig. S9, Table S1). From 
288 the data, $\mathrm{SO}_{4}{ }^{*}$ contribution up to $90 \%$ of total FLU degradation can be estimated (Table S1).

289 At $\mathrm{pH} 6.5$, reaction of $\mathrm{SO}_{4}{ }^{-}-$with $\mathrm{HO}^{-}$in order to generate ${ }^{\circ} \mathrm{OH}$ must be of less extent, 290 because of the low concentration of $\mathrm{HO}^{-}$in solution at this $\mathrm{pH}$ value and the low reaction rate, $k_{H O^{-}} \mathrm{SO}^{\cdot-}=7 \times 10^{7} \mathrm{M}^{-1} \mathrm{~s}^{-1} \quad 29,35$.

292 Therefore, decomposition of $\mathrm{H}_{2} \mathrm{O}_{2}$ or $\mathrm{S}_{2} \mathrm{O}_{8}{ }^{2-}$ by $\mathrm{FeOOH}$ could proceed through a 293 reaction chain, which lead to the production of radical species $14,15,36$ :

$\equiv \mathrm{Fe}^{\mathrm{III}}+\mathrm{H}_{2} \mathrm{O}_{2} \longrightarrow \equiv \mathrm{Fe}^{\mathrm{II}}+\mathrm{HO}_{2} \cdot / \mathrm{O}_{2}^{\cdot-}+\mathrm{H}^{+}$

$294 \equiv \mathrm{Fe}^{\mathrm{III}}+\mathrm{O}_{2}^{--} \longrightarrow \equiv \mathrm{Fe}^{\mathrm{II}}+\mathrm{O}_{2}$

$295 \equiv \mathrm{Fe}^{\mathrm{II}}+\mathrm{H}_{2} \mathrm{O}_{2} \longrightarrow \equiv \mathrm{Fe}^{\mathrm{III}}+\mathrm{HO}^{-}+\cdot \mathrm{OH}$

$\equiv \mathrm{Fe}^{\mathrm{III}}+\mathrm{S}_{2} \mathrm{O}_{8}{ }^{2-} \longrightarrow \equiv \mathrm{Fe}^{\mathrm{II}}+\mathrm{S}_{2} \mathrm{O}_{8}{ }^{-}$

296

297

$\equiv \mathrm{Fe}^{\mathrm{II}}+\mathrm{S}_{2} \mathrm{O}_{8}{ }^{2-} \longrightarrow \equiv \mathrm{Fe}^{\mathrm{III}}+\mathrm{SO}_{4}{ }^{2-}+\mathrm{SO}_{4}{ }^{-}$

Likewise, Mn could also initiate $\mathrm{H}_{2} \mathrm{O}_{2}$ or PS decomposition to generate radical species following equations $29,37,38,39$ :

301

$\equiv \mathrm{Mn}^{\mathrm{IV}}+\mathrm{H}_{2} \mathrm{O}_{2} \rightarrow \quad \equiv \mathrm{Mn}^{\mathrm{III}}+\mathrm{HO}_{2} \cdot \mathrm{O}_{2}{ }^{--}+\mathrm{H}^{+}$

302

$\equiv \mathrm{Mn}^{\mathrm{IV}} / \mathrm{Mn}^{\mathrm{III}}+\mathrm{O}_{2} \cdot-\longrightarrow \quad \equiv \mathrm{Mn}^{\mathrm{III}} / \mathrm{Mn}^{\mathrm{II}}+\mathrm{O}_{2}$

303

$\equiv \mathrm{Mn}^{\mathrm{III}}+\mathrm{H}_{2} \mathrm{O}_{2} \rightarrow \equiv \mathrm{Mn}^{\mathrm{IV}}+\mathrm{HO}^{-}+\cdot \mathrm{OH}$

304

$\equiv \mathrm{Mn}^{\mathrm{II}}+\mathrm{H}_{2} \mathrm{O}_{2} \longrightarrow \equiv \mathrm{Mn}^{\mathrm{III}}+\mathrm{HO}^{-}+\cdot \mathrm{OH}$

$\equiv \mathrm{Mn}^{\mathrm{IV}}+\mathrm{S}_{2} \mathrm{O}_{8}{ }^{2-} \longrightarrow \equiv \mathrm{Mn}^{\mathrm{III}}+\mathrm{S}_{2} \mathrm{O}_{8}{ }^{-}$

$\equiv \mathrm{Mn}^{\mathrm{III}}+\mathrm{S}_{2} \mathrm{O}_{8}{ }^{2-} \longrightarrow \equiv \mathrm{Mn}^{\mathrm{IV}}+\mathrm{SO}_{4}{ }^{--}+\mathrm{SO}_{4}{ }^{2-}$

$307 \equiv \mathrm{Mn}^{\mathrm{II}}+\mathrm{S}_{2} \mathrm{O}_{8}{ }^{2-} \longrightarrow \equiv \mathrm{Mn}^{\mathrm{III}}+\mathrm{SO}_{4}{ }^{-}+\mathrm{SO}_{4}{ }^{2-}$

Because the conduction bands of $\mathrm{Mn}^{\mathrm{IV}}$ (hydr)oxides are at much lower energies than those of the Fe $\mathrm{FII}^{\mathrm{III}}$ (hydr)oxides (band gaps in Pyrolusite is $1.0 \mathrm{eV} v s 2.5 \mathrm{eV}$ for goethite) ${ }^{40}$, the photoreductive dissolution of $\mathrm{Mn}^{\mathrm{IV}}$-oxides is more energetically feasible. However, two oneelectron transfer steps or a single two-electron step may be operative during photo-assisted 
313 reduction of $\mathrm{MnO}_{2}$, i.e., $\mathrm{Mn}^{\mathrm{IV}}$ can be photochemically reduced to $\mathrm{Mn}^{\mathrm{III}}$ with or without further reduction into $\mathrm{Mn}^{\mathrm{II}}{ }^{43-45}$. Waite et al., ${ }^{43}$ have reported that the $365-\mathrm{nm}$ light irradiation $\mathrm{MnO}_{2}$ can produce $\mathrm{Mn}^{\mathrm{II}}$, while other authors reported that photo-generation of $\mathrm{Mn}^{\mathrm{III}}$ occurs under 400-nm light irradiation of $\mathrm{MnO}_{2}$, with no further reduction into $\mathrm{Mn}^{\mathrm{II}}{ }^{44}$. Furthermore, creation of photoexcited precursor species, which exhibits more facile electron transfer than occurs thermally, may take place under irradiation ${ }^{40-45}$.

In the present work, $\mathrm{Mn}^{\mathrm{II}}$ aqueous concentration did not exceed $2 \mu \mathrm{M}$ even after $10 \mathrm{~h}$ of irradiation of $\mathrm{MnO}_{2}$ suspension in $\mathrm{N}_{2}$ purging solution at $\mathrm{pH} 6.5$, most likely due to strong binding of $\mathrm{Mn}^{2+}$ to $\mathrm{MnO}_{2}$ surfaces at $\mathrm{pH}$ 6.5. Consistently, environmental concentrations of $\mathrm{Mn}^{2+}$ under oxic conditions are found generally very low, particularly in absence of dissolved organic matter ${ }^{41-43}$.

Taken together, these results shows that the greater efficiency achieved under irradiation could be explained by the higher production of active species, i.e., hydroxyl or sulfate radicals and/or reduced metal ions (Fe (II) or Mn(II)) ${ }^{35-37}$. The UVA irradiation may promote the photo-assisted reduction of $\mathrm{Fe}^{\mathrm{III}}$ to $\mathrm{Fe}^{\mathrm{II}}$ or $\mathrm{Mn}^{\mathrm{IV}}$ to $\mathrm{Mn}^{\mathrm{III}}$ and/or $\mathrm{Mn}^{\mathrm{II}}$, which subsequently reacts with $\mathrm{H}_{2} \mathrm{O}_{2}$ or $\mathrm{S}_{2} \mathrm{O}_{8}{ }^{2-}$ generating ${ }^{\bullet} \mathrm{OH}$ or $\mathrm{SO}_{4}{ }^{--}$.

\subsection{Impact of pre-equilibration time on the mineralization extent}

As total mineralization is not achieved by UVA and oxidants $\left(\mathrm{H}_{2} \mathrm{O}_{2}\right.$ or PS), we examine here the implications of the one-electron transfer reaction in enhancing the elimination of target compounds by hydroxyl/sulfate radical-based technology. For this purpose, we investigated the impact of pre-equilibration time between antibiotics and metal-oxides on the mineralization extent. 
When oxidants and solids were simultaneously added to FLU solution under UVA irradiation (i.e., without pre-equilibration), the mineralization extent increased progressively and achieved a steady-state after $32 \mathrm{~h}$ of reaction time (Fig. S7). An equilibration of solid with FLU for $24 \mathrm{~h}$ before oxidant addition and UVA irradiation did not affect the mineralization extent (Fig. S10). Note that only adsorption occurs during the pre-equilibration period (solid + FLU) according to the mass balance. In both cases, the highest mineralization extent was found for the UVA/ $\mathrm{MnO}_{2}$ system whatever the used oxidant.

When NOR and solids are allowed for equilibration in aqueous solution over $24 \mathrm{~h}$ for $\mathrm{H}_{2} \mathrm{O}_{2}$ /Goethite, PS/Goethite, $\mathrm{H}_{2} \mathrm{O}_{2} / \mathrm{MnO}_{2}$ and $\mathrm{PS} / \mathrm{MnO}_{2}$ systems, respectively (Fig.3). UVA irradiation after the pre-equilibration time allowed higher mineralization extent, but the complete mineralization was only achieved in the PS/UVA/MnO ${ }_{2}$ system (Fig. 3).

As the electron transfer reaction between $\mathrm{NOR}$ and $\mathrm{MnO}_{2}$ was relatively fast, we have repeated the previous experiments but by lowering the pre-equilibration time to $1 \mathrm{~h}$ (Fig. 4). Similar mineralization extents were obtained in the $\mathrm{PS} / \mathrm{MnO}_{2}$ and $\mathrm{PS} / \mathrm{UVA} / \mathrm{MnO}_{2}$ systems, but within a shorter total time (i.e., $40 \mathrm{~h}$ instead of $54 \mathrm{~h}$ of total reaction time). On the other hand, longer pre-equilibration time (i.e., $48 \mathrm{~h}$ ) was tested for goethite since its reaction kinetic with NOR was relatively slow (See Fig. S11). Only a slight improvement in TOC removal (i.e., less than 8\%) was observed, suggesting that larger pre-equilibration time does not significantly affect the mineralization extent in the case of goethite.

\subsection{Role of oxide-bound $\mathrm{Mn}^{\mathrm{II}}$ in mineralization enhancement}

The mineralization improvement takes place only when NOR and the metal oxide are important in presence of $\mathrm{MnO}_{2}$ (more redox active), and more particularly when PS was used 
as an oxidant in the second stage. These results can be explained if the reaction products, i.e. NOR byproducts and Mn species generating during the first stage, are more reactive than the starting compounds. To assess the reactivity of NOR byproducts with sulfate radicals, Laser Flash Photolysis (LFP) experiments were performed for the mother NOR solution $(\mathrm{t}=0$, called NOR) and those reacted with $\mathrm{MnO}_{2}$ after $1 \mathrm{~h}$ and $24 \mathrm{~h}$ of reaction (called here $\mathrm{NOR}_{\mathrm{ox}}$ ). The results showed very similar reactivity constants with sulfate radicals, i.e. $k$ (NOR, SO4-) $=$ 1.7.10 $\mathrm{L} \mathrm{mgC}^{-1} \mathrm{~s}^{-1}$ close to the values determined after oxidation by $\mathrm{MnO}_{2}$ (i.e., $k$ ( $\mathrm{NORox} \mathrm{SO}^{-}$ )$\left._{1 \mathrm{~h}}=k\left(\text { NORox, } \mathrm{SO}^{-}\right)_{24 \mathrm{~h}}=1 \cdot 6 \cdot 10^{7} \mathrm{~L} \mathrm{mgC}^{-1} \mathrm{~s}^{-1}\right)($ See Table S2). This result may rule out the hypothesis that the higher mineralization rate results from the greater reactivity of NOR byproducts with radical species.

Reductive dissolution of $\mathrm{MnO}_{2}$ by NOR may lead to generate reduced $\mathrm{Mn}$ ions and thus $\mathrm{Mn}^{\mathrm{II}}$ or $\mathrm{Mn}^{\mathrm{III}}$-rich $\mathrm{MnO}_{2}$ system. Because of the great tendency for manganese ions to be adsorbed at the oxide surface at the working $\mathrm{pH}$, the exact concentration of $\mathrm{Mn}^{2+}$ generated from the redox reaction $\mathrm{MnO}_{2} / \mathrm{NOR}$ cannot be determined. However, adsorption isotherm determined at $\mathrm{pH} 6.5$ indicated a great affinity of $\mathrm{Mn}^{2+}$ to $\mathrm{MnO}_{2}$ with an adsorption capacity lying at $\sim 0.1 \mu \mathrm{mol} \mathrm{m}{ }^{-2}$ (Fig. S12). In addition, AOS of Mn in the reacted solid decreased to 3.76, thereby underscoring a partial reduction of $\mathrm{MnO}_{2}$ though no structural modification was observed by XRD (Fig. S13). Only UVA irradiation seems to induce oxygen depletion in the pyrolusite structure, yet no visible structural change can be determined (Table S3, Fig. S13). This is in agreement with previous works which showed a great stability (low solubility) of pyrolusite under well-oxidized conditions. ${ }^{46-47}$

To assess the contribution of $\mathrm{Mn}^{\mathrm{II}}$ in the advanced oxidation reaction (i.e. the second stage), we added $\mathrm{Mn}^{2+}$ (24 $\mu \mathrm{M}$ to be equivalent to the stoichiometric amount of NOR) in $\mathrm{MnO}_{2}$ suspension before adding NOR and starting the oxidation reaction (Fig. S14). The 
results showed a complete mineralization of NOR after $60 \mathrm{~h}$ of reaction, while increasing of $\mathrm{Mn}^{\mathrm{II}}$ concentration to $48 \mu \mathrm{M}$ led to a complete mineralization within a shorter time (i.e., $44 \mathrm{~h}$ instead of 60 h) (Fig. S14). Therefore, complete NOR mineralization could be achieved either by performing a pre-equilibration stage between $\mathrm{NOR}$ and $\mathrm{MnO}_{2}$ or by adding $\mathrm{Mn}^{\mathrm{II}}$ to the $\mathrm{MnO}_{2}$ suspension. It is worth noting that $\mathrm{Mn}^{\mathrm{II}}$ ions in homogeneous solution are not active for PS activation and NOR degradation (Fig. S15), and the mineralization is only achieved when $\mathrm{Mn}{ }^{\mathrm{II}}$ was added to $\mathrm{MnO}_{2}$ suspension. As it is generally reported for $\mathrm{Fe}^{\mathrm{II}}{ }^{48}$, this higher reactivity of surface-bound $\mathrm{Mn}^{\mathrm{II}}$ compared to aqueous $\mathrm{Mn}^{\mathrm{II}}$ may be ascribed to its bandgap decrease, which warrants future research.

The contribution of the solid was further confirmed by repeating the oxidation experiment but by removing the solid from solution (e.g., through filtration) after the preequilibration period (Fig. S16). Indeed, the mineralization extent of NOR dropped to less than $21 \pm 2 \%$. When the same experiment was performed with goethite a slight decrease of mineralization was observed, $53 \pm 2 \%$ when goethite was removed from the solution after 24 h of pre-equilibration time against $69 \pm 2 \%$ in presence of goethite (Fig. S16).

As a further attempt to gain insights into the enhanced reactivity of reacted $\mathrm{MnO}_{2}$ system, Mn oxides with lower valence states $\left(\mathrm{Mn}^{\mathrm{III}}\right)$ as in manganite $\left(\gamma-\mathrm{Mn}^{\mathrm{III}} \mathrm{OOH}\right)$ were investigated. $37 \%$ and complete mineralization were obtained with $\mathrm{PS} / \mathrm{MnOOH}$ and $\mathrm{PS} / \mathrm{MnOOH} / \mathrm{UVA}$ processes, respectively (Fig. 5), compared to 30 and $65 \%$ with $\mathrm{PS} / \mathrm{MnO}_{2}$ and $\mathrm{PS} / \mathrm{MnO}_{2} / \mathrm{UVA}$ processes, respectively (Fig. 2). When NOR and manganite were allowed for $1 \mathrm{~h}$ pre-equilibration before starting the oxidation reaction, complete mineralization was also observed in the PS/MnOOH/UVA system, but only after $35 \mathrm{~h}$ of reaction time (Fig. 5). This implies that the photo-generation of $\mathrm{Mn}^{\mathrm{II}}$ enhances the oxidation performance, regardless of the starting solid, e.g. $\mathrm{Mn}^{\mathrm{IV}} \mathrm{O}_{2}$ or $\mathrm{Mn}^{\mathrm{III}} \mathrm{OOH}$. 
Taken together, these results suggest that oxide-bound $\mathrm{Mn}^{\mathrm{II}}$ is key in catalyzing the oxidation reaction and enhancing the mineralization rate under UVA irradiation through a redox cycle. $\mathrm{Mn}^{\mathrm{II}}$ species or photogenerated $\mathrm{Mn}^{\mathrm{II}}$ species react first with oxidants to produce radicals through eqs. 13 and 16 . Then, $\mathrm{Mn}^{\mathrm{II}}$ species could be re-generated via photo-reduction of active sites on $\mathrm{MnO}_{\mathrm{x}}$ or $\mathrm{MnOOH}$ surfaces, which in turn react with $\mathrm{PS}$ or $\mathrm{H}_{2} \mathrm{O}_{2}$ to generate $\mathrm{SO}_{4}{ }^{-}$or ${ }^{\circ} \mathrm{OH}$. The higher fluoroquinolone degradation in the presence of PS compared to $\mathrm{H}_{2} \mathrm{O}_{2}$ can be probably ascribed to the $i$ ) higher ability of $\mathrm{Mn}^{\mathrm{II}}$ in PS activation compared to $\mathrm{H}_{2} \mathrm{O}_{2}$ and $i$ ) higher selectivity of generated sulfate radical (e.g. less subjected for scavenging effects compared to $\left.{ }^{\circ} \mathrm{OH}\right)$ toward fluoroquinolones. It is worth noting that photo-assisted generation and/or regeneration of $\mathrm{Mn}^{\mathrm{II}}$ may require a certain time, as TOC removal kinetics exhibited a two-step behavior, i.e. sharp decay after a first slow phase, particularly in the PS/UVA system, and regardless of the underlying surface, $\mathrm{Mn}^{\mathrm{IV}} \mathrm{O}_{2}$ (Fig. 4) or $\mathrm{Mn}^{\mathrm{III}} \mathrm{OOH}$ (Fig. $5)$.

\section{Environmental implications}

We have notably demonstrated that a short pre-equilibration time between redox-active minerals and antibiotics is crucial to achieve total elimination or mineralization of compounds. Reduced metal ions generated during the pre-equilibration stage and contacted/adsorbed to oxide minerals are highly active in triggering oxidation reactions and achieving complete mineralization. This key promoter of oxidation reaction is generated in situ with no other reactant added. $\mathrm{MnO}_{\mathrm{x}}$ system exhibits more reactivity than $\mathrm{FeOOH}$ because (i) of its higher reduction potential $\left(\mathrm{Mn}^{\mathrm{III}} / \mathrm{Mn}^{\mathrm{II}}\right.$ being more electron acceptor than $\left.\mathrm{Fe} \mathrm{III}^{\mathrm{II}} / \mathrm{Fe}^{\mathrm{II}}\right)$, (ii) two one-electron transfer steps or a single two-electron step may be operative during $\mathrm{Mn}^{\mathrm{IV}} \mathrm{O}_{2}$ reduction, and/or (iii) photoreductive dissolution of $\mathrm{Mn}^{\mathrm{IV}} \mathrm{O}_{\mathrm{x}}$ is more thermodynamically favorable, irrespective of the presence or absence of complexing ligands. 
In the first stage, the oxidative transformation is attributed to sequential one electrontransfer reactions, i.e., electron transfer within the precursor complex formed between the molecule and the surface-bound metal, that result in reductive dissolution of the oxide and oxidation of the molecule. In the second stage, the byproducts are attacked by radical species, generated upon addition of $\mathrm{H}_{2} \mathrm{O}_{2}$ or $\mathrm{S}_{2} \mathrm{O}_{8}{ }^{2-}$ under UVA irradiation, which achieved mineralization via probably ring-opening reactions. If the compound (e.g. FLU) solely adsorbs to oxide surfaces with no redox reaction during the first stage of reaction, a preequilibration period does not impact the mineralization extent regardless of the duration of the first stage.

\section{Oxide-bound $\mathrm{Mn}^{\mathrm{II}}$ is essential in catalyzing oxidation reaction and then producing greater} amounts of radical species through a photo-assisted redox cycle. Light enhanced the rate of $\mathrm{Mn}^{2+}$ generation, which in turn reacts with $\mathrm{H}_{2} \mathrm{O}_{2}$ or $\mathrm{S}_{2} \mathrm{O}_{8}{ }^{2-}$ to produce more radical species and then oxidize/mineralize target compounds. This shows the greater ability of $\mathrm{MnO}_{2}$ as compared to iron oxides, in inducing electron transfer reactions with antibiotics, and then triggering their subsequent radical-based degradation. These results provide a novel strategy towards the application of redox active minerals in a dynamic two-step treatment process, where the redox byproducts generated in-situ during the first stage strongly contribute in achieving total removal of TOC. Because of the great affinity of manganese ions for Mnoxide surfaces at neutral $\mathrm{pH}$, the $\mathrm{Mn}^{2+}$ leaching from the oxide surface is very limited, and much below the wastewater discharge limits. Therefore, the developed system will be of scientific significance in both Mn-based oxidation reactions and practical wastewater treatment processes.

\section{Acknowledgments}

We gratefully acknowledge the Région Bretagne and Institut Universitaire de France for providing financial support 
461 Supporting Information Available. Solubility tests and speciation $v s \mathrm{pH}$, additional kinetics 462 data in sorption/desorption and formation of byproducts; adsorption of $\mathrm{Mn}^{2+}$ to $\mathrm{MnO}_{2}$; 463 oxidation/mineralization kinetics for FLU and NOR under different experimental conditions, 464 LFP experimental datasets. This information is available free of charge via the Internet at 465 http://pubs.acs.org/. 
467

468

469

470

471

472

473

474

475

476

477

478

479

480

481

482

483

484

485

486

487

488

489

490

\section{References}

1. Cornell, R. M.; Schwertmann, U. The Iron Oxides Structure, Properties, Reactions, Occurences and Uses; Wiley-VCH: Weinheim; Cambridge, 2003.

2. Hochella, M. F.; Lower, S. K.; Maurice, P. A.; Penn, R. L.; Sahai, N.; Sparks, D. L.; Twining, B. S. Nanominerals, Mineral Nanoparticles, and Earth Systems. Science 2008, 319 (5870), 1631-1635.

3. Stone, A. T. Reductive dissolution of manganese (III/IV) oxides by substituted phenols. Environ. Sci. Technol. 1987, 21, 979-988.

4. McBride, M. B. Adsorption and oxidation of phenolic compounds by iron and manganese oxides. Environ. Toxicol. Chem. 1987, 51(6), 1466-1472.

5. Feitosa-Felizzola, J.; Hanna, K.; Chiron, S. Adsorption and transformation of selected human-used macrolide antibacterial agents with iron(III) and manganese(IV) oxides. Environ. Poll. 2009, 157 (4), 1317-1322.

6. Zhang, H.; Huang, C.-H. Oxidative transformation of fluoroquinolone antibacterial agents and structurally related amines by manganese oxide. Environ. Sci. Technol. 2005, 39, 4474- 4483 .

7. Rubert, K. F.; Pedersen J.A. Kinetics of Oxytetracycline Reaction with a Hydrous Manganese Oxide. Environ. Sci. Technol. 2006, 40 (23), 7216-7221.

8. Lin, K.; Liu, W.; Gan, J. Reaction of tetrabromobisphenol A (TBBPA) with manganese dioxide: Kinetics, products, and pathways. Environ. Sci. Technol. 2009, 43 (12), 44804486.

9. Remucal, C. K.; Ginder-Vogel, M. A critical review of the reactivity of manganese oxides with organic contaminants. Environ. Sci. Process. Impacts 2014, 16, 1247-1266. 
10. Martin, S.; Shchukarev, A.; Hanna, K.; Boily, J.-F., Kinetics and Mechanisms of Ciprofloxacin Oxidation on Hematite Surfaces. Environ. Sci. Technol. 2015, 49, $12197-12205$.

11. Salter-Blanc, A. J.; Bylaska, E. J.; Lyon, M. A.; Ness, S. C.; Tratnyek, P. G. StructureActivity Relationships for Rates of Aromatic Amine Oxidation by Manganese Dioxide. Environ. Sci. Technol. 2016, 50 (10), 5094-5102.

12. Balgooyen, S.; Alaimo, P. J.; Remucal, C. K.; Ginder-Vogel, M. Structural transformation of $\mathrm{MnO}_{2}$ during the oxidation of Bisphenol A. Environ. Sci. Technol. 2017, 51, 60536062.

13. Huang, J.; Zhong, S.; Dai, Y.; Liu, C-C.; Zhang, H. Effect of $\mathrm{MnO}_{2}$ Phase Structure on the Oxidative Reactivity toward Bisphenol A Degradation. Environ. Sci. Technol. 2018, 52 (19), 11309-11318.

14. Watts, R. J.; Sarasa, J.; Loge, F. J.; Teel, A. L. Oxidative and reductive pathways in manganese-catalyzed Fenton's reactions. J. Environ. Eng. 2005, 131, 158-164.

15. Liu, H.; Bruton, T. A.; Doyle, F. M.; Sedlak, D. L. In Situ Chemical Oxidation of Contaminated Groundwater by Persulfate: Decomposition by Fe (III)- and Mn (IV)Containing Oxides and Aquifer Materials. Environ. Sci. Technol. 2014, 48, 10330-10336.

16. Avetta, P.; Pensato, A.; Minella, M.; Malandrino, M.; Maurino, V.; Minero, C.; Hanna, K.; Vione, D. Activation of Persulfate by Irradiated Magnetite: Implications for the Degradation of Phenol under Heterogeneous Photo-Fenton-Like Conditions. Environ. Sci. Technol. 2015, 49, 1043-1050.

17. Neta, P.; Huie, R. E.; Ross, A. B. Rate constants for reactions of inorganic radicals in aqueous solution. J. Phys. Chem. Ref. Data. 1988, 17, 1027-1284.

18. Huie, R. E.; Clifton, C. L.; Neta, P. Electron transfer reaction rates and equilibria of the carbonate and sulfate radical anions. Radiat. Phys. Chem. 1991, 38 (5), 477- 481. 
19. Jia, A.; Wan, Y.; Xiao, Y.; Hu, J. Occurrence and Fate of Quinolone and Fluoroquinolone Antibiotics in a Municipal Sewage Treatment Plant. Water Res. 2012, 46 (2), 387-394.

20. Zhang, T.; Li, B. Occurrence, Transformation, and Fate of Antibiotics in Municipal Wastewater Treatment Plants. Crit. Rev. Env. Sci. Tec. 2011, 41 (11), 951-998.

21. Marsac, R.; Martin, S.; Boily, J.-F.; Hanna, K. Oxolinic Acid Binding at Goethite and Akaganéite Surfaces: Experimental Study and Modeling. Environ. Sci. Technol. 2016, 50 (2), 660-668.

22. Murray, J. W. The surface chemistry of hydrous manganese dioxide. J. Colloid Interface Sci. 1974, 46, 357-371.

23. Yu, C.; Boily, J-F.; Shchukarev, A.; Drake, H.; Song, Z.; Hogmalm, KJ, Åström, ME. A cryogenic XPS study of Ce fixation on nanosized manganite and vernadite: Interfacial reactions and effects of fulvic acid complexation. Chem. Geol. 2018, 483, 304-311.

24. Zhao, H.; Zhu, M.; Li, W.; Elzinga, E. J., Villalobos, M., Liu, F.; Zhang, Feng, J.X., Sparks, D. L. Redox Reactions between Mn(II) and Hexagonal Birnessite Change Its Layer Symmetry. Environ. Sci. Technol., 2016, 4, 50-56.

25. Huang, W.; Bianco, W.; Brigante, M.; Mailhot, G. UVA-UVB activation of hydrogen peroxide and persulfate for advanced oxidation processes: Efficiency, mechanism and effect of various water constituents. J. Haz. Mat., 2018, 347, 279-287.

26. Zhang, H.; Huang, $\mathrm{CH}$. Adsorption and oxidation of fluoroquinolone antibacterial agents and structurally related amines with goethite, Chemosphere 2007, 66 (8), 1502-1512.

27. Paul, T.; Liu, J.; Machesky, M.L.; Strathmann, T. Adsorption of zwitterionic fluoroquinolone antibacterials to goethite: A charge distribution-multisite complexation model. J. Coll. Int. Sci. 2014, 428, 63-72. 
28. Furman, O.; Laine, D. F.; Blumenfeld, A.; Teel, A. L.; Shimizu, K.; Cheng, I. F.; Watts, R. J. Enhanced reactivity of superoxide in water - solid matrices. Environ. Sci. Technol. 2009, 43, 1528-1533.

29. Liu, H.; Bruton, T. A.; Li, W.; Buren, J. V.; Prasse, C.; Doyle, F. M.; Sedlak D. L. Oxidation of Benzene by Persulfate in the Presence of Fe(III)- and Mn(IV)-Containing Oxides: Stoichiometric Efficiency and Transformation Products. Environ. Sci. Technol. 2016, 50, 890-898.

30. Fang, G.; Chen, X.; Wu, W.; Liu, C.; Dionysiou, D. D.; Fan, T.; Wang, Y.; Zhu, C.; Zhou D. Mechanisms of Interaction between Persulfate and Soil Constituents: Activation, Free Radical Formation, Conversion, and Identification. Environ. Sci. Technol. 2018, 52, $14352-14361$.

31. Zhu, S.; Li, X.; Kang J.; Duan, X.; Wang, S. Persulfate Activation on Crystallographic Manganese Oxides: Mechanism of Singlet Oxygen Evolution for Nonradical Selective Degradation of Aqueous Contaminants. Environ. Sci. Technol. 2018, 53, 1, 307-315.

32. Neta, P.; Madhavan, V.; Zemel, H.; Fessenden, R.W. Rate constants and mechanism of reaction of $\mathrm{SO}_{4}{ }^{-}$- with aromatic compounds. J. Am. Chem. Soc. 1977, 99,163-164.

33. Buxton, G. V.; Greenstock, C. L.; Helman, W. P.; Ross, A. B. Critical review of rate constants for reactions of hydrated electrons, hydrogen atoms and hydroxyl radicals $\left({ }^{\circ} \mathrm{OH}\right.$ $/ \mathrm{O}_{2}{ }^{-}$) in aqueous solution. J. Phys. Chem. Ref. Data 1988, 17, 513-886.

34. Gonzalez-Olmos, R.; Martin, M. J.; Georgi, A.; Kopinke, F.-D.; Oller, I.; Malato, S. Fezeolites as heterogeneous catalysts in solar Fenton-like reactions at neutral pH. Appl. Catal. B: Environ. 2012, 125, 51-58.

35. Minella, M.; Marchetti, G.; De Laurentiis, E.; Malandrino, M.; Maurino, V.; Minero, C.; Vione, D.; Hanna, K. Photo-Fenton oxidation of phenol with magnetite as iron source. Appl. Catal. B: Environ. 2014, 154, 102-109. 
36. Kim, E. J.; Oh, D.; Lee, C. S.; Gong, J.; Kim, J. Manganese oxide nanorods as a robust Fenton-like catalyst at neutral pH: Crystal phase-dependent behavior. Catal. Today 2017, 282, 71-76.

37. Xu, Y.; Lin, H.; Li, Y.; Zhang H. The mechanism and efficiency of $\mathrm{MnO}_{2}$ activated persulfate process coupled with electrolysis. Sci. Total Environ. 2017, 609, 644-654.

38. Luther, G. W. III. The role of one- and two-electron transfer reactions in forming thermodynamically unstable intermediates as barriers in multi-electron redox reactions. Aquat. Geochem. 2010, 16, 395-420.

39. Baral, S.; Lume-Pereira, C.; Janata, E. ; Henglein, A. Chemistry of colloidal manganese dioxide. 2. Reaction with superoxide anion $\left(\mathrm{O}_{2}{ }^{--}\right)$and hydrogen peroxide (pulse radiolysis and stop flow studies). J. Phys. Chem. 1985, 89, 5779-5783.

40. Sherman, D. M. Electronic structures of iron(III) and manganese(IV) (hydr)oxide minerals: Thermodynamics of photochemical reductive dissolution in aquatic environments. Geochim. Cosmochim. Acta, 2005, 69, 13, 3249-3255.

41. Sunda, W. G.; Huntsman, S. A.; Harvey ,G. R. Photoreduction of manganese oxides in seawater and its geochemical and biological implications. Nature, 1983, 301, 234-236.

42. Sunda, W. G.; Huntsman, S. A. Photoreduction of manganese oxides in seawater. Mar. Chem. 1994, 46, 133-152.

43. Waite, T. D.; Wrlgley, I. C.; Szymczak R. Photoassisted Dissolution of a Colloidal Manganese Oxide in the Presence of Fulvic Acid. Environ. Sci. Technol. 1988, 27 (7), 778-785.

44. Marafatto, F. F.; Strader, M. L.; Gonzalez-Holguera, J.; Schwartzberg, A.; Gilbert, B.; Peña, J. Rate and mechanism of the photoreduction of birnessite $\left(\mathrm{MnO}_{2}\right)$ nanosheets. Proc. Nat. Acad. Sci., 2015, 1-6. 
45. Klausen, J.; Haderlein, S.B.; Schwarzenbach, R. P. Oxidation of substituted anilines by aqueous $\mathrm{MnO}_{2}$ : Effect of Co-solutes on initial and quasi-steady-state kinetics. Environ. Sci. Technol. 1997, 31, 2642- 2649.

46. Post, J.E. Manganese oxide minerals: Crystal structures and economic and environmental significance. Proc. Natl. Acad. Sci. 1999, 96, 3447-3454.

47. Birkner, N.; Navrotsky, A. Rapidly reversible redox transformation in nanophase manganese oxides at room temperature triggered by changes in hydration. Proc. Natl. Acad. Sci. 2014, 111, 6209-6214.

48. Alexandrov, V.; Rosso K.M. Ab initio modeling of Fe(II) adsorption and interfacial electron transfer at goethite $(\alpha-\mathrm{FeOOH})$ surfaces, Phys. Chem. Chem. Phys., 2015,17, 14518-14531.

49. An, T.; Yang, H.; Song, W.; Li, G.; Luo, H.; Cooper, W. J. Mechanistic considerations for the advanced oxidation treatment of fluoroquinolone pharmaceutical compounds using $\mathrm{TiO}_{2}$ heterogeneous catalysis. J. Phys. Chem. A 2010, 114, 2569-2575. 
Tables

Table 1. Second-order rate constants between flumequine (FLU) and norfloxacin (NOR) 616 determined by laser flash photolysis with hydroxyl and sulfate radicals at different $\mathrm{pH}$ values.

\begin{tabular}{|c|c|c|c|}
\hline Molecule & $\mathbf{p H}$ & $k_{H O} .\left(\mathrm{M}^{-1} \mathrm{~s}^{-1}\right)$ & $k_{S O_{4}}-\left(\mathbf{M}^{-1} \mathbf{s}^{-1}\right)$ \\
\hline \multirow[t]{2}{*}{ FLU } & 3 & $1.80 \pm 0.17 \times 10^{10}$ & $1.86 \pm 0.30 \times 10^{9}$ \\
\hline & 9 & $6.34 \pm 0.13 \times 10^{9}$ & $1.81 \pm 0.12 \times 10^{9}$ \\
\hline \multirow[t]{3}{*}{ NOR } & 3.5 & & $2.09 \pm 0.17 \times 10^{9}$ \\
\hline & 7.5 & $\begin{array}{c}6.18 \pm 0.18 \times 10^{9} \\
(\text { ref.49) }\end{array}$ & $1.36 \pm 0.14 \times 10^{9}$ \\
\hline & 11 & & $1.31 \pm 0.30 \times 10^{9}$ \\
\hline
\end{tabular}

617 
Figure 1: Kinetics of NOR removal and $\mathrm{Mn}^{2+}$ release under dark conditions at $\mathrm{pH} 6.5 \pm 0.1$ :

622 $[\mathrm{NOR}]=24 \mu \mathrm{M} ;\left[\mathrm{MnO}_{2}\right]=0.027 \mathrm{~g} \mathrm{~L}^{-1}\left(10 \mathrm{~m}^{2} \mathrm{~L}^{-1}\right)$.

623

624

625

626

627

628

629

630

631

632

633

634

635

636

637

638

639

640

Figure 2: Removal kinetics of $\mathrm{NOR}_{\text {tot }}$ (empty symbols) and $\mathrm{TOC}_{\text {tot }}$ (full symbols) with simultaneous addition of solids and oxidants under dark and irradiation conditions at $\mathrm{pH} 6.5 \pm$ 0.1. $[\mathrm{NOR}]_{\mathrm{o}}=24 \mu \mathrm{M} ;\left[\mathrm{H}_{2} \mathrm{O}_{2}\right]_{\mathrm{o}}=\left[\mathrm{S}_{2} \mathrm{O}_{8}{ }^{2-}\right]_{\mathrm{o}}=0.5 \mathrm{mM} ;$ goethite $]_{\mathrm{o}}=0.118 \mathrm{~g} \mathrm{~L}^{-1}\left(10 \mathrm{~m}^{2} \mathrm{~L}^{-1}\right)$; $\left[\mathrm{MnO}_{2}\right]_{\mathrm{o}}=0.027 \mathrm{~g} \mathrm{~L}^{-1}\left(10 \mathrm{~m}^{2} \mathrm{~L}^{-1}\right)$.

Figure 3: Removal kinetics of $\mathrm{NOR}_{\text {tot }}$ (empty symbols) and $\mathrm{TOC}_{\text {tot }}$ (full symbols) after $24 \mathrm{~h}$ of pre-equilibration time under dark and irradiation conditions at $\mathrm{pH} 6.5 \pm 0.1$ : $[\mathrm{NOR}]_{\mathrm{o}}=24$ $\mu \mathrm{M} ;\left[\mathrm{H}_{2} \mathrm{O}_{2}\right]_{\mathrm{o}}=\left[\mathrm{S}_{2} \mathrm{O}_{8}{ }^{2-}\right]_{\mathrm{o}}=0.5 \mathrm{mM} ;$ goethite $]_{\mathrm{o}}=0.118 \mathrm{~g} \mathrm{~L}^{-1}\left(10 \mathrm{~m}^{2} \mathrm{~L}^{-1}\right) ;\left[\mathrm{MnO}_{2}\right]_{\mathrm{o}}=0.027 \mathrm{~g} \mathrm{~L}^{-1}$ $\left(10 \mathrm{~m}^{2} \mathrm{~L}^{-1}\right)$. The arrow indicates the moment where oxidant addition and/or UVA irradiation take place.

Figure 4: Removal kinetics of $\mathrm{NOR}_{\text {tot }}$ (empty symbols) and $\mathrm{TOC}_{\text {tot }}$ (full symbols) with $\mathrm{MnO}_{2}$ and $\mathrm{S}_{2} \mathrm{O}_{8}{ }^{2-}(\mathrm{PS})$ under dark and irradiation conditions at $\mathrm{pH} 6.5 \pm 0.1$ : $[\mathrm{NOR}]_{\mathrm{o}}=24 \mu \mathrm{M}$; $\left[\mathrm{S}_{2} \mathrm{O}_{8}{ }^{2-}\right]_{\mathrm{o}}=0.5 \mathrm{mM} ;\left[\mathrm{MnO}_{2}\right]_{\mathrm{o}}=0.027 \mathrm{~g} \mathrm{~L}^{-1}\left(10 \mathrm{~m}^{2} \mathrm{~L}^{-1}\right) ;$ Pre-equilibration time $=1 \mathrm{~h}$.

Figure 5: Removals kinetic of $\mathrm{NOR}_{\text {tot }}$ (empty symbols) and $\mathrm{TOC}_{\text {tot }}$ (full symbols) using $\mathrm{MnOOH}$ without or with pre-equilibration time under dark and irradiation conditions and at pH $6.5 \pm 0.1:[\mathrm{NOR}]_{\mathrm{o}}=24 \mu \mathrm{M} ;\left[\mathrm{S}_{2} \mathrm{O}_{8}{ }^{2-}\right]_{\mathrm{o}}=0.5 \mathrm{mM} ;[\mathrm{MnOOH}]_{\mathrm{o}}=0.154 \mathrm{~g} \mathrm{~L}^{-1}\left(10 \mathrm{~m}^{2} \mathrm{~L}^{-1}\right)$. The vertical dashed line indicates the moment (1h) where oxidant addition and/or UVA irradiation take place. 


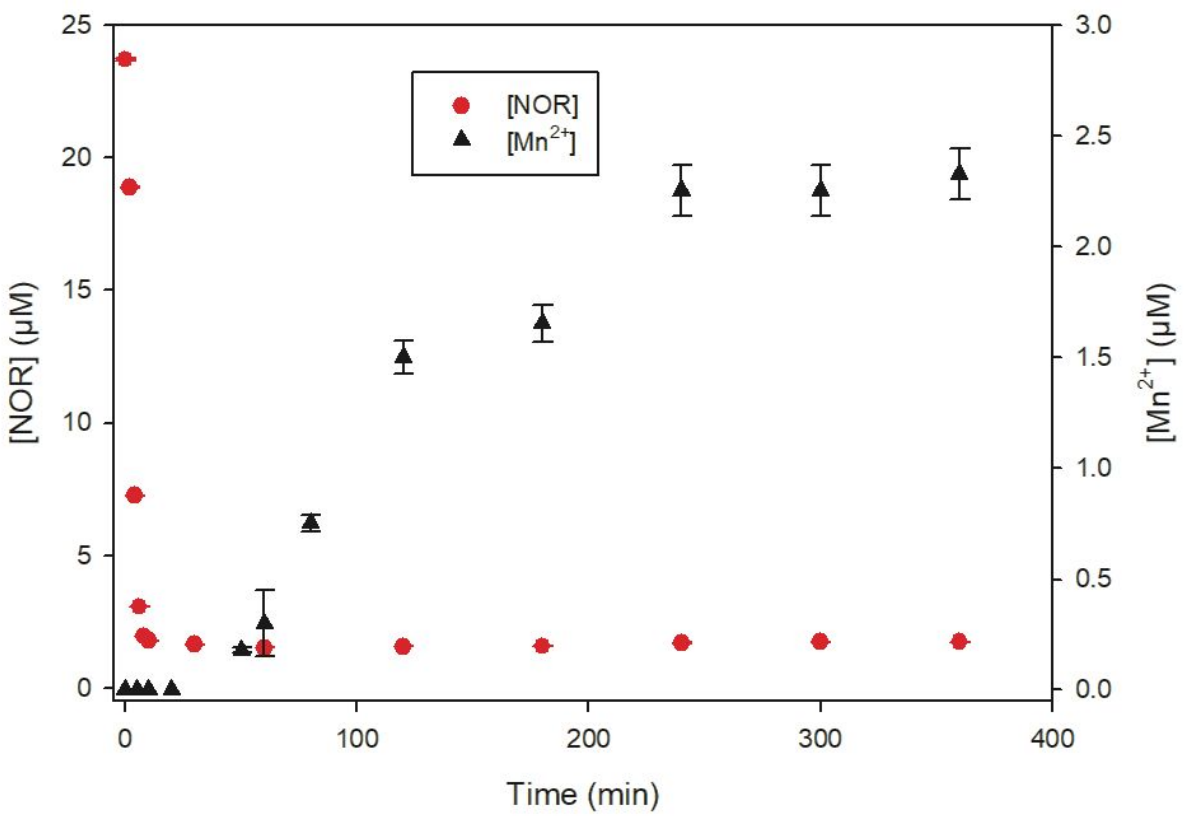

643 Figure 1

644

645

646

647

648

649

650

651

652

653

654

655

656

657

658

659

660

661 

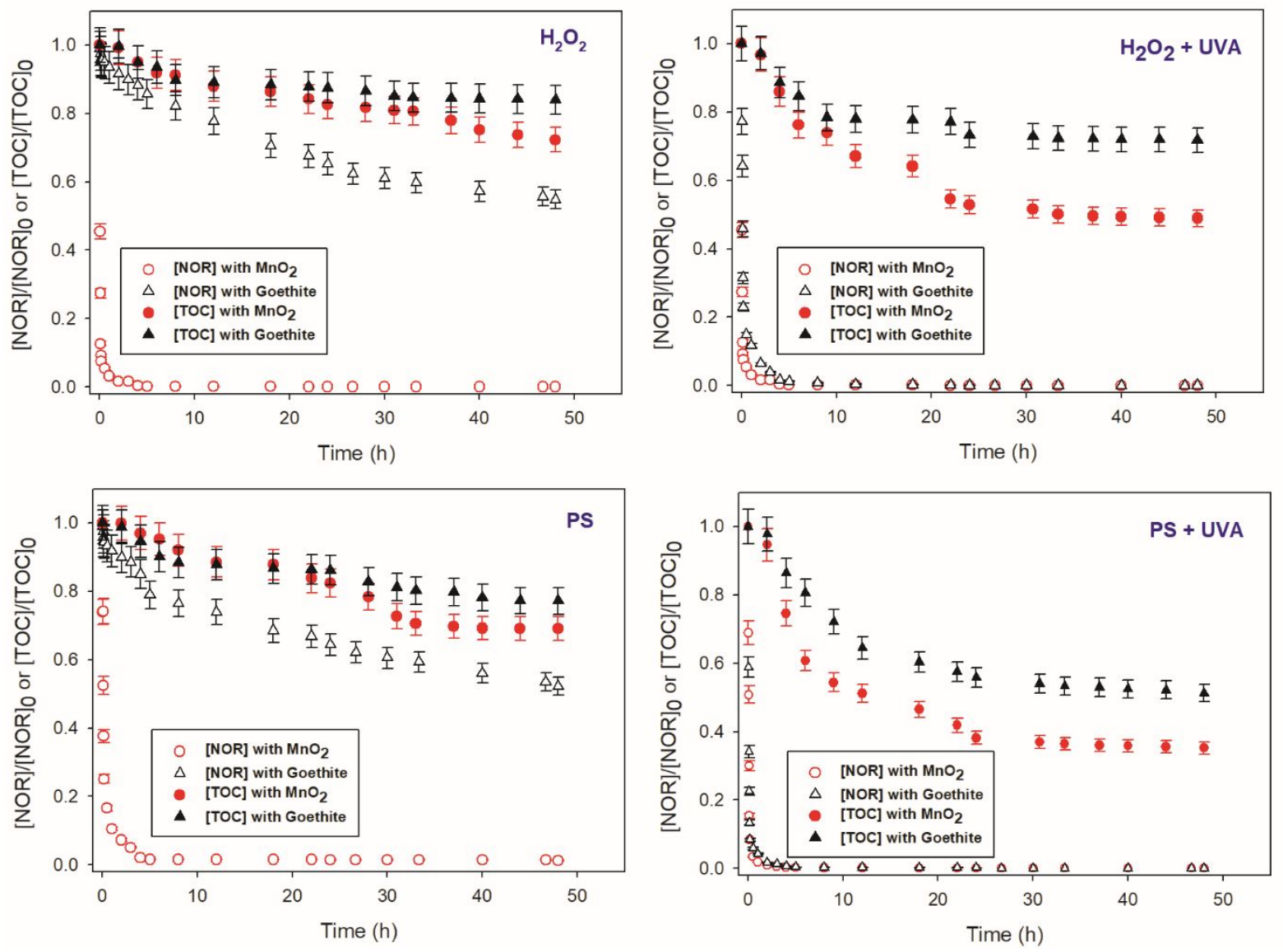

Figure 2

664

665

666

667

668

669

670

671

672

673

674

675

676

677 

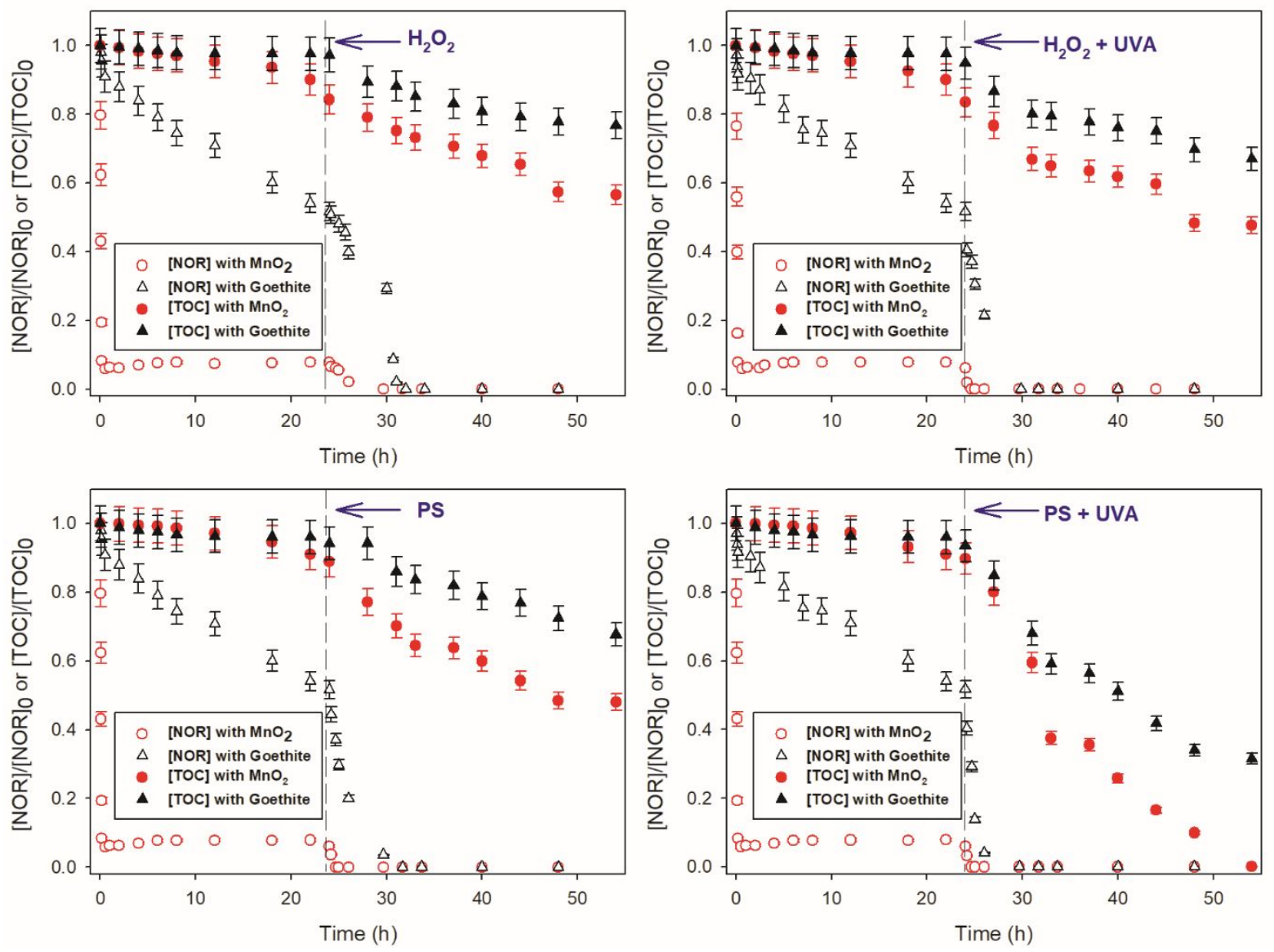

680

681

Figure 3

682

683

684

685

686

687

688

689

690

691 

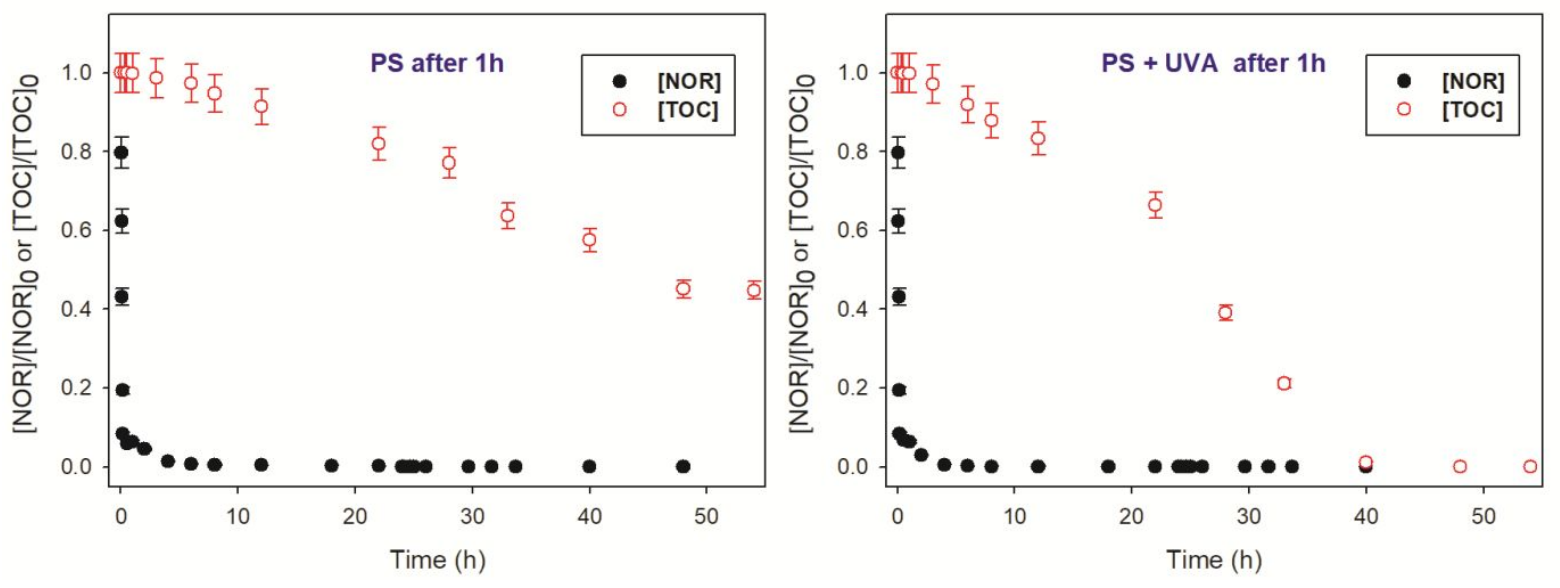

692

693

Figure 4

694

695

696

697

698

699

700

701 

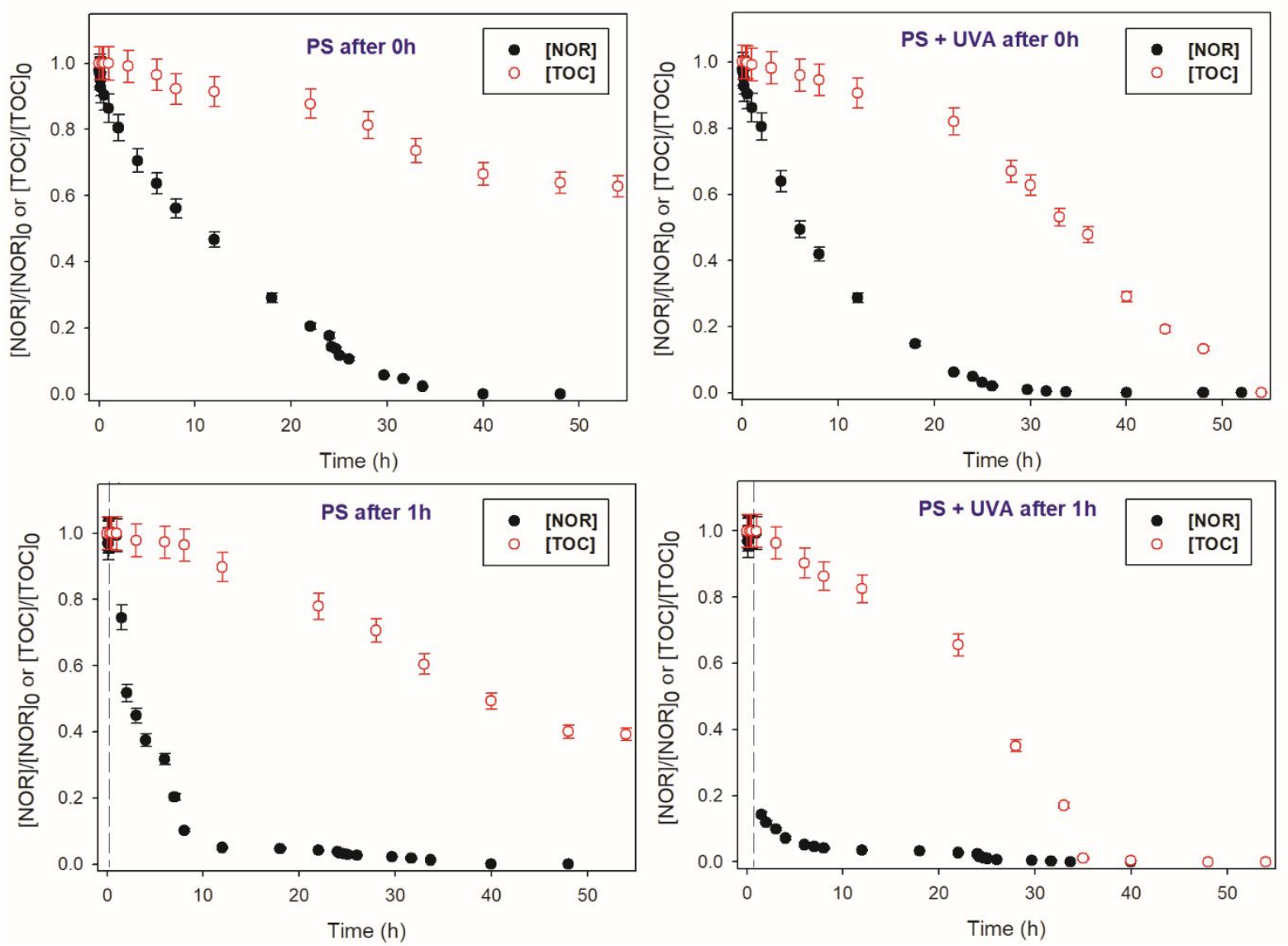

703

Figure 5 


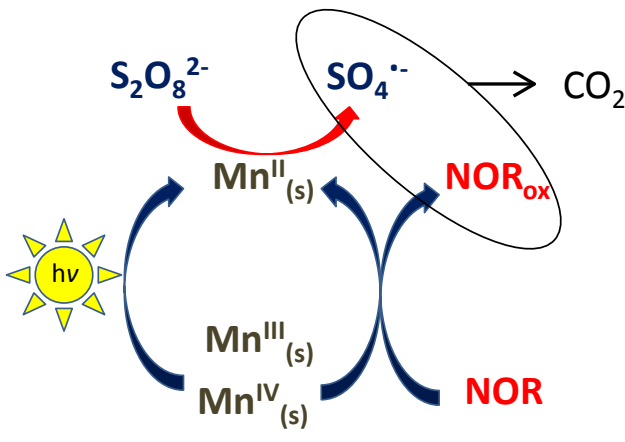

707

708

709

710

711 